\title{
ULTRASONIC DATA ANALYSIS USING A COMPUTER
}
R. D. Sachs
J. D. Elkins
J. H. Smith

\section{UNION CARBIDE CORPORATION NUCLEAR DIVISION OAK RIDGE Y-12 PLANT}

operated for the ATOMIC ENERGY COMMISSION under U. S. GOVERNMENT Contract W-7405 eng 26

UNION CARBIDE
OAK RIDGE Y-12 PLANT

P. O. BOX $Y$

OAK RIDGE, TENNESSEE 37830 


\section{DISCLAIMER}

This report was prepared as an account of work sponsored by an agency of the United States Government. Neither the United States Government nor any agency Thereof, nor any of their employees, makes any warranty, express or implied, or assumes any legal liability or responsibility for the accuracy, completeness, or usefulness of any information, apparatus, product, or process disclosed, or represents that its use would not infringe privately owned rights. Reference herein to any specific commercial product, process, or service by trade name, trademark, manufacturer, or otherwise does not necessarily constitute or imply its endorsement, recommendation, or favoring by the United States Government or any agency thereof. The views and opinions of authors expressed herein do not necessarily state or reflect those of the United States Government or any agency thereof. 


\section{DISCLAIMER}

Portions of this document may be illegible in electronic image products. Images are produced from the best available original document. 
Printed in the United States of America. Available from National Technical Information Service

U.S. Department of Commerce

5285 Port Royal Road, Springfield, Virginia 22151

Price: Printed Copy $\$ 3.00$; Microfiche $\$ 0.95$

This report was prepared as an account of work sponsored by the United States Government. Neither the United States nor the United States Atomic Energy Commission, nor any of their employees, nor any of their contractors, subcontractors, or their employees, makes any warranty, express or implied, or assumes any legal liability or responsibility for the accuracy, completeness or usefulness of any information, apparatus, product or process disclosed, or represents that its use would not infringe privately owned rights.

Reference to a company or product name does not imply approval or recommendation of the product by Union Carbide Corporation or the U S Atomic Energy Commission to the exclusion of others that may meet specifications. 


\title{
ULTRASONIC DATA ANALYSIS USING A COMPUTER
}

\author{
R. D. Sachs \\ J. D. Elkins \\ J. H. Smith
}

\section{Oak Ridge Y-12 Plant}

P.O. Box Y, Oak Ridge, Tennessee 37830

operated for the U.S. ATOMIC ENERGY COMMISSION bY UNION CARBIDE CORPORATION-NUCLEAR DIVISION under Contract W.7405-eng-26

Date Issued - February 22, 1972 NOTICE

This report was prepared as an account of work sponsored by the United States Government. Neither the United States nor the United States Atomic Energy Commission, nor any of their employees, nor any of their contractors, subcontractors, or their employees, makes any warranty, express or implied, or assumes any legal liability or responsibility for the accuracy, completeness or usefulness of any information, apparatus, product or process disclosed, or represents that its use would not infringe privately owned rights. 
THIS PAGE

\section{WAS INTENTIONALLY \\ LEFT BLANK}




\section{DISTRIBUTION}

Atomic Energy Commission - ORO

Cape, J. D.

Keller, C. A.

Zachry, D. S.; Jr

Dow - Rocky F lats

Anderson, L. J.

Lawrence Livermore Laboratory

Bulden, B. O.

McMillin, K. .

Vitale, J.

\section{Oak Ridge Gaseous Diffusion Plant}

Jordan, R. G:

Long, E. C.

Wilcox, W. J., Jr

\section{Oak Ridge Y-12 Plant}

Arrowood, J. L.

Austin, L. A.

Bernander, N. K.

Bigelow, R. R.

Boser, G. R.

Bright, G. R.

Briscoe, O. W.

Burditt, R. B.

Burkhart, L. E.

Chapman, S. L.

Denny, A. (3)

Elkins, J. D. (15)

Ellingson, R. D.

Ferree, D. V.

Fletcher, D. R.

Foulk, D. L.

Garber, J. W.

Hemphill, L. F.

Henry, J. J.

Jackson, V. C.

Jones, F. W. 
KahI, K. G.

Keith, Alvin

Kite, H. T.

Knowles, C. M.

Koerner, D. W.

Long, P. J.

Mason, D. L.

Mc Lendon, J. D.

Mitchel, G. W.

Moyer, W. M.

Mundt, F. D.

Neal, R. E:

Nicely, J. W.

Noey, J. L.

Oliphant, G. W.

Olmstead, C. R.

Ross, W. D.

Scott, G. W.

Smith, R. D.

Snow, S. G.

Stoner, H. H.

Trotter, T. C.

Van Dusen, D. L.

Weathersby, W. E.

White, W. W.

Yaggi, W. J.

Y-12 Central Files (5)

Y-12 Central Files (master copy)

$Y-12$ Centra! Files (route)

Y.12 Central Files $(Y-12 R C)$

\section{Paducah Gaseous Diffusion Plänt}

Winkel, R. A.

Sandia - Livermore

Cofield, R. E.

In addition, this report is distributed in accordance with the category UC-37, Instruments, as given in the USAEC Standard Distribution Lists for Unclassified Scientific and Technical Reports, TID-4500. 


\section{ABSTRACT}

A digital computer is used to analyze the data obtained from the ultrasonic inspection of a weld. The computer is interfaced to a standard ultrasonic flaw detector and to the scanning mechanism. The computer can automatically determine the size of a flaw and its location on the test part as the test is bring conducted semiautomatically. 


\section{CONTENTS}

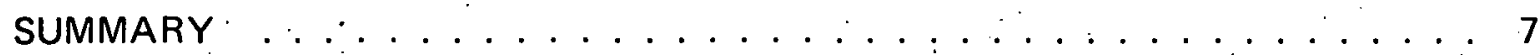

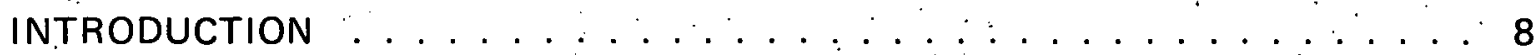

ULTRASONIC TESTING USING A COMPUTER . . . . . . . . . . . . 9

Description of the Test . . . . . . . . . . . . . . . . . . 9

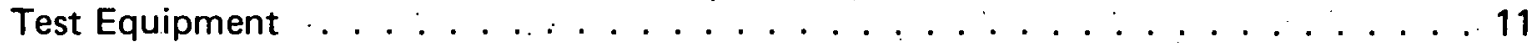

Program Criteria . . . . . . . . . . . . . . . . . . 11

General Description of the Computer Program . . . . . . . . . . . . . . 13

System Test Results . . . . . . . . . . . . . . . . ......... . 14

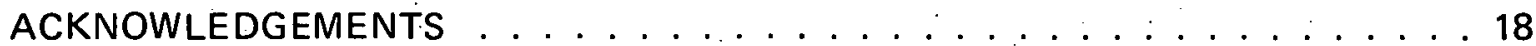




\section{SUMMARY}

A digital computer is being used at the Oak Ridge Y-12 Plant ${ }^{(a)}$ to analyze the data obtained from the ultrasonic. inspection of a weld. The computer is interfaced to a standard ultrasonic flaw detector and to the scanning mechanism. Encoders are used to provide position data, and the amplitudes of the reflected indications are obtained from the ultrasonic flaw detector. The computer can automatically determine the size of the flaw indication and its location on the test part as the test is being conducted semiautomatically. At the completion of the test, the computer provides a printout of the test results on a teletypewriter, and the data can be stored on digital tape. In addition, the analog recording that is normally obtained is still available for cross reference.

This computerized ultrasonic system is checked against an ultrasonic standard prior to each inspection to assure that the instrumentation is still functioning properly. :

(a) Operated for the US Atomic Energy Commission by the Union Carbide Corporation's Nuclear Division. 


\section{INTRODUCTION}

As a result of earlier work, (b) it was suggested that a digital computer could perform a comparative analysis of ultrasonic inspections and print out the results. Since then a functional system has become a reality.

The system consists of a computer and ultrasonic equipment, and has evolved from the need for an ultrasonic inspection to determine the integrity of a welded step joint using pulse-echo techniques. The test was designed to verify the specified weld penetration; in this instance, to fully fuse 50 percent of the joint. The test is also capable of detecting flaw conditions such as voids, cold shuts, and porosity which exist in the weld root area. By assigning some arbitrary limit or norm to the conditions which reflect very little sound energy, it is possible to recommend corrective actions before inferior welds are produced. An evaluation of these random and relatively low-level signals with a computer establishes a very rigid process control which, in turn, assures a high production efficiency for quality welds.

This report describes a specific testing situation where a small process computer is used to directly analyze the data as they are collected. The term "CUDAS" is used as an acronym for Computer Ultrasonic Data Analysis System; "MASS" is used as an acronym for Manual Analysis Scan System.

(b) Elkins, J. A., Sachs, R. D., and Austin, L. A.; An Investigation of Ultrasonic Data Analysis Using a Multichannel Analyzer or Equivalent Circuitry, Y-1698; Union Carbide Corporation-Nuclear Division, Oak Ridge Y-12 Plant, Oak Ridge, Tennessee; December 10, 1969. 


\section{ULTRASONIC TESTING USING A COMPUTER}

\section{DESCRIPTION OF THE TEST}

The test piece is immersed in demineralized water, and a short-focus, $5-\mathrm{MHz}$ transducer is positioned to produce shear waves in the part which are incident at 45 degrees to the step corner. The three illustrations in Figure 1 show the sound paths of interest. Figure 1(a) depicts three reflection sources for transducer locations at which the incident angle is held constant. For the full-weld condition shown in Figure 1(b), the reflection source for Position 1 of the transducer is no longer available. The wave continues to the inside surface where it is reflected and lost. Figure 1 (c) shows the situation for a weld with insufficient penetration. The step corner reflects a signal which is characteristic of the reflecting area remaining from the lack of weld penetration. The primary variable that is of interest is the height $(h)$ of this step corner.

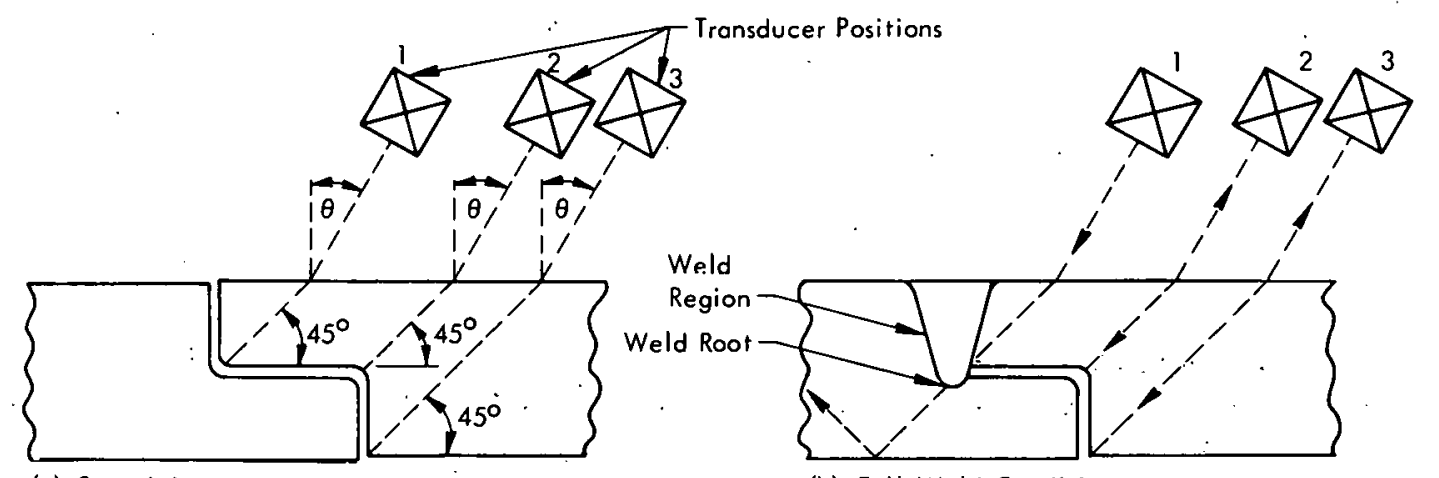

(o) Step Joint

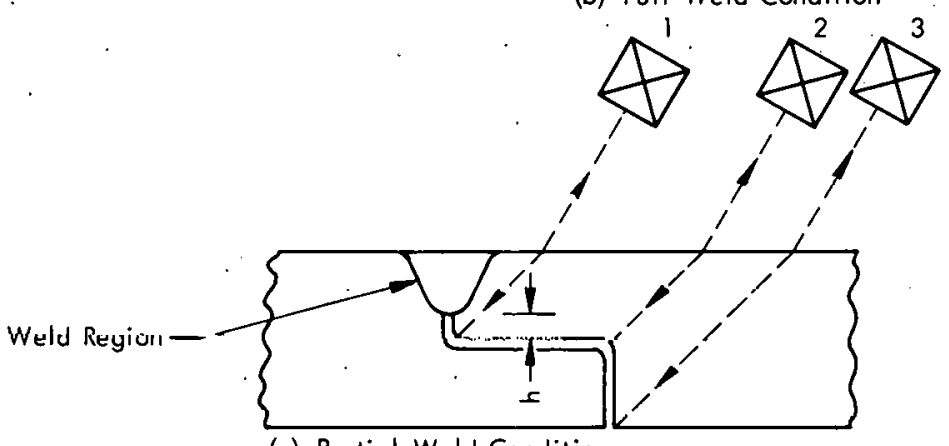

(c) Partial-Weld Condition

Figure 1. ULTRASONIC SOUND PATHS AND TRANSDUCER POSITIONS FOR THREE TEST PARTS.

A test standard containing various corner heights, h, was prepared by Elox machining a series of rectangular slots into the base of a groove with a depth equivalent to the step joint. Figure 2 indicates the ar.rangement of the slots. Although a number of slots were provided from a corner height of 2 mils up to values equal to 50 mils, only the three smallest corner heights $(h=2,5$, and 10 mils $)$ were utilized in this work. Prior to machining the slots, a weld pass was made in the groove zone to simulate the metallurgical conditions which would exist in an actual test part. Each slot had a length of 150 mils. Typically, the slot gap was on the order of 2 to 3 mils, but the width dimension has no bearing on the amount of sound reflected. The tracings of Figure 3 show the respective amplitudes of the signal reflected 
from the slots. The pulser-receiver gain was established by setting the signal amplitude reflected from the 10-mil-deep slot to the same value for each test. The value chosen was 88 percent of a saturated signal.
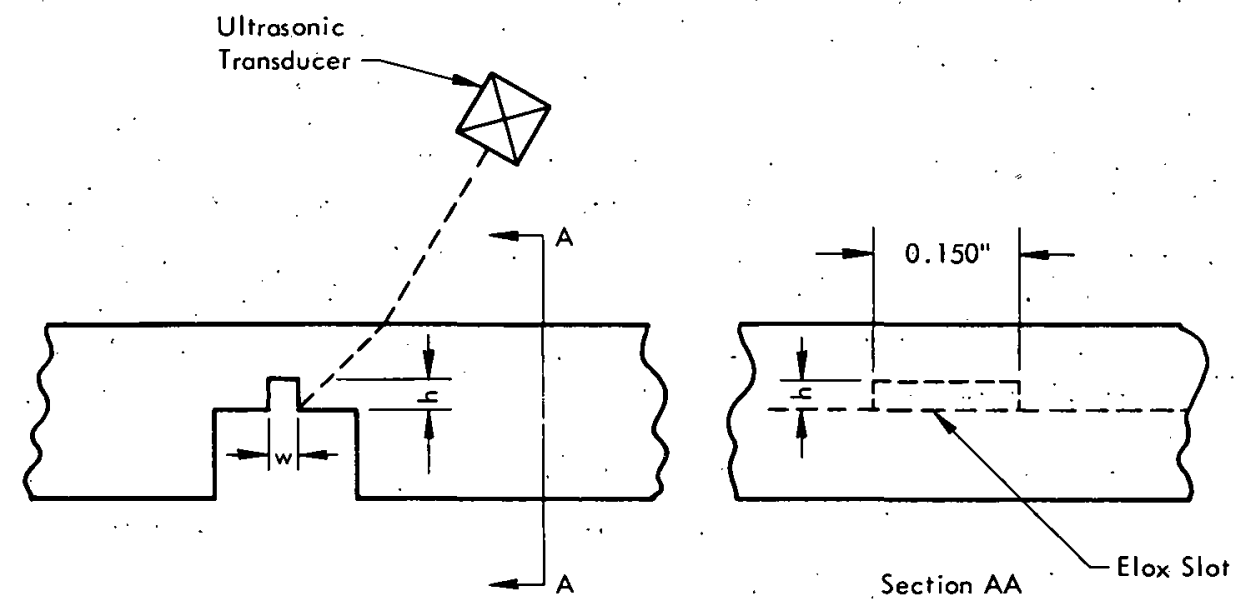

Figure 2. TEST PIECE WITH A RECTANGULAR SLOT AT THE BASE OF A GROOVE.

These reference amplitudes permit the flaws to be classified. Weld-root conditions, such as spherical voids and randomly oriented cold shuts, cannot be accurately determined as to size; however, a relative comparison to known signal sources provides information which indicates the quality of the weld. Several overlapping data scans are taken in order to thoroughly traverse the weld root area. The breadth of a single scan is of the order of 50 mils, and the transducer is indexed about 12 mils between scans. A single scan covers the length of the test piece.

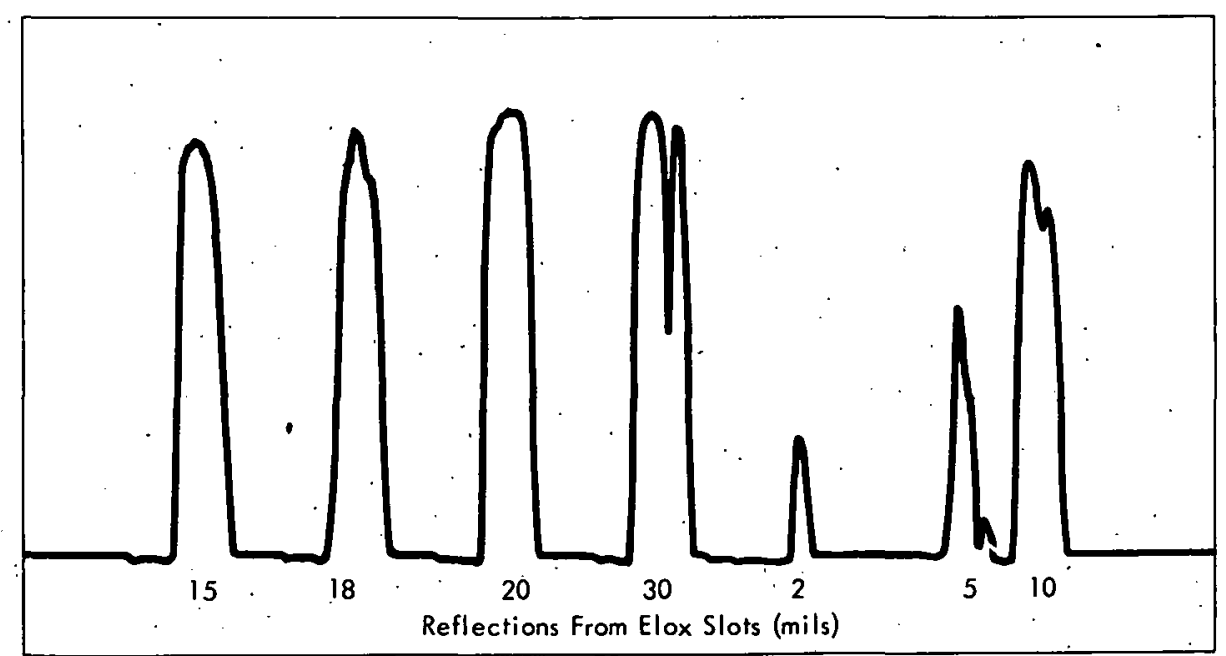

Figure 3. AMPLITUDES OF SIGNALS REFLECTED FROM SLOTS OF VARIOUS HEIGHTS. 


\section{TEST EOUIPMENT}

The basic test equipment consists of the following items (see Figure 4): a Model 725 Immerscope, a Brush 250 recorder, an immersion tank, a movable workpiece platform (remotely controlled), a transducer manipulator, a control console, an absolute position encoder (for the work platform), an analog-to-digital converter (ADC), a Digital Equipment Corporation PDP-8/I computer, an added 4-K memory, and a Teletype ASR-33 head.

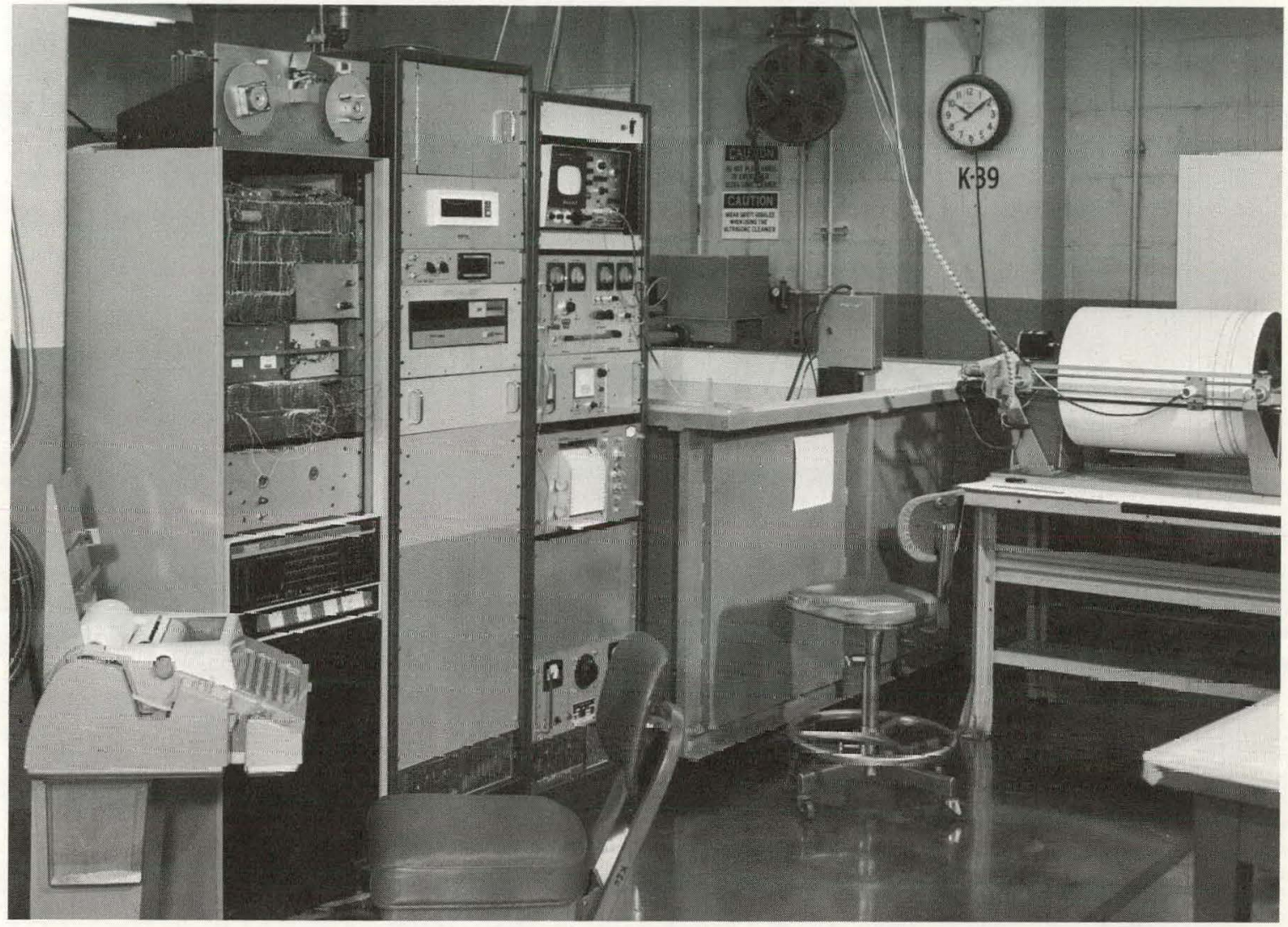

140084

Figure 4. ULTRASONIC DATA ANALYSIS TEST EQUIPMENT.

The analog output of the Model 725 Immerscope goes from a baseline voltage of $+1.0 \mathrm{~V}$ to a saturation level at $+6.0 \mathrm{~V}$, and provides the input to the pen recorder and analog-to-digital converter (Figure 5). Charts are still maintained for permanent record purposes even though the data analysis is performed by the computer.

\section{PROGRAM CRITERIA}

The following considerations were fundamental in preparing the computer program:

1. All flaws equivalent to or greater in amplitude than the 2-mil-deep reference slot signal were accounted for. 


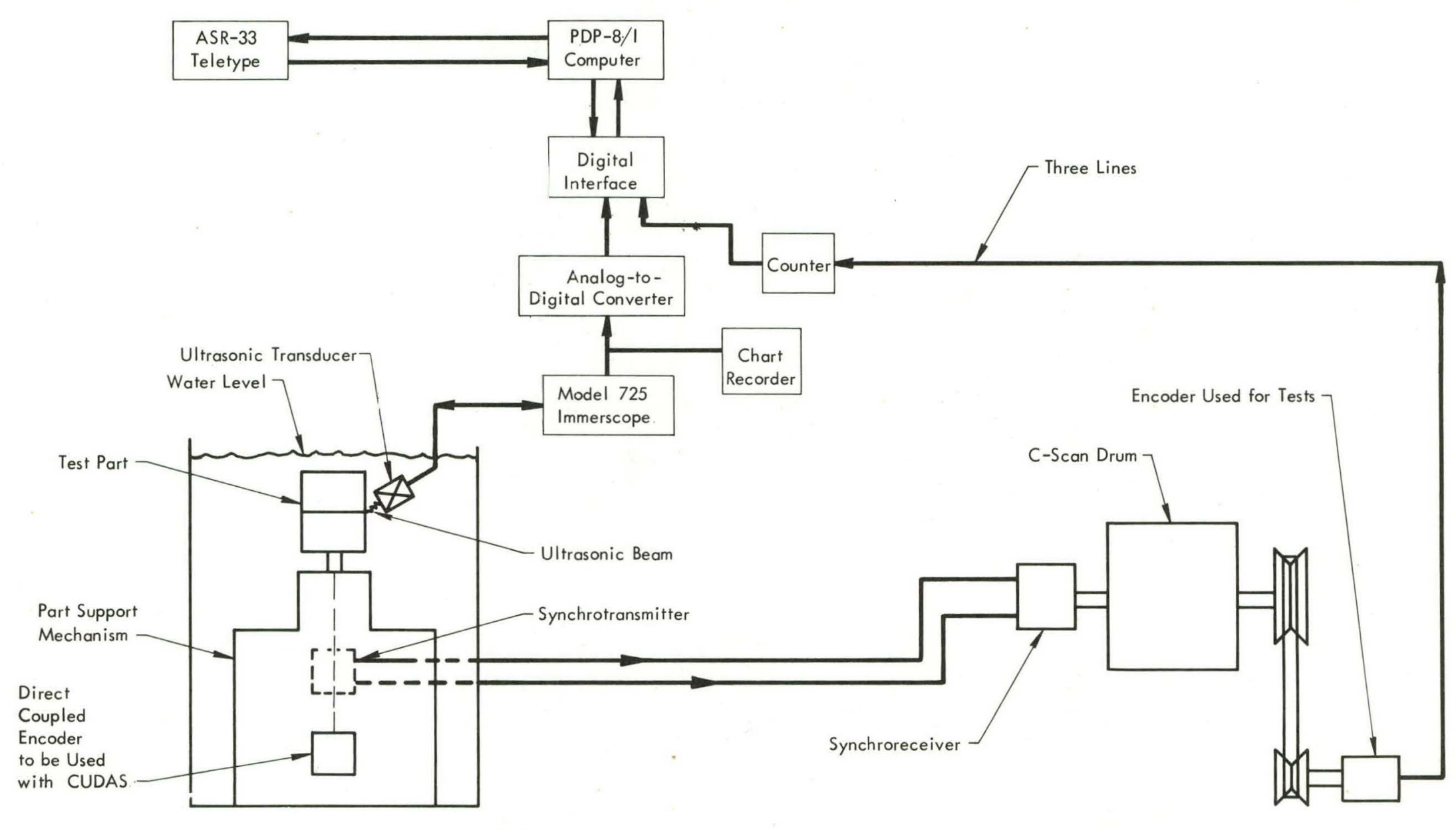

FigUre 5. INFORMATION FLOW FOR THE COMPUTERIZED ULTRASONIC DATA ANALYSIS SYSTEM (CUDAS). 
2. All flaws closer together than 120 mils were considered as a single, continuous flaw (refer to Figure 6).

3. All flaws which reached or exceeded the reference amplitude of the 5-mil-deep slot were separately accounted for.

4. All flaws which reached or exceeded the reference amplitude of the 10-mil-deep slot were separately accounted for.

5. Flaws lying in the range from the 10-mil slot level to signal saturation require categorizing by determining a percent of the saturation value.

6. An upgrading capability was needed to assure that each flaw was seen in a maximized sense and was accounted for as the overlapping scans were obtained (refer to Figure 6).

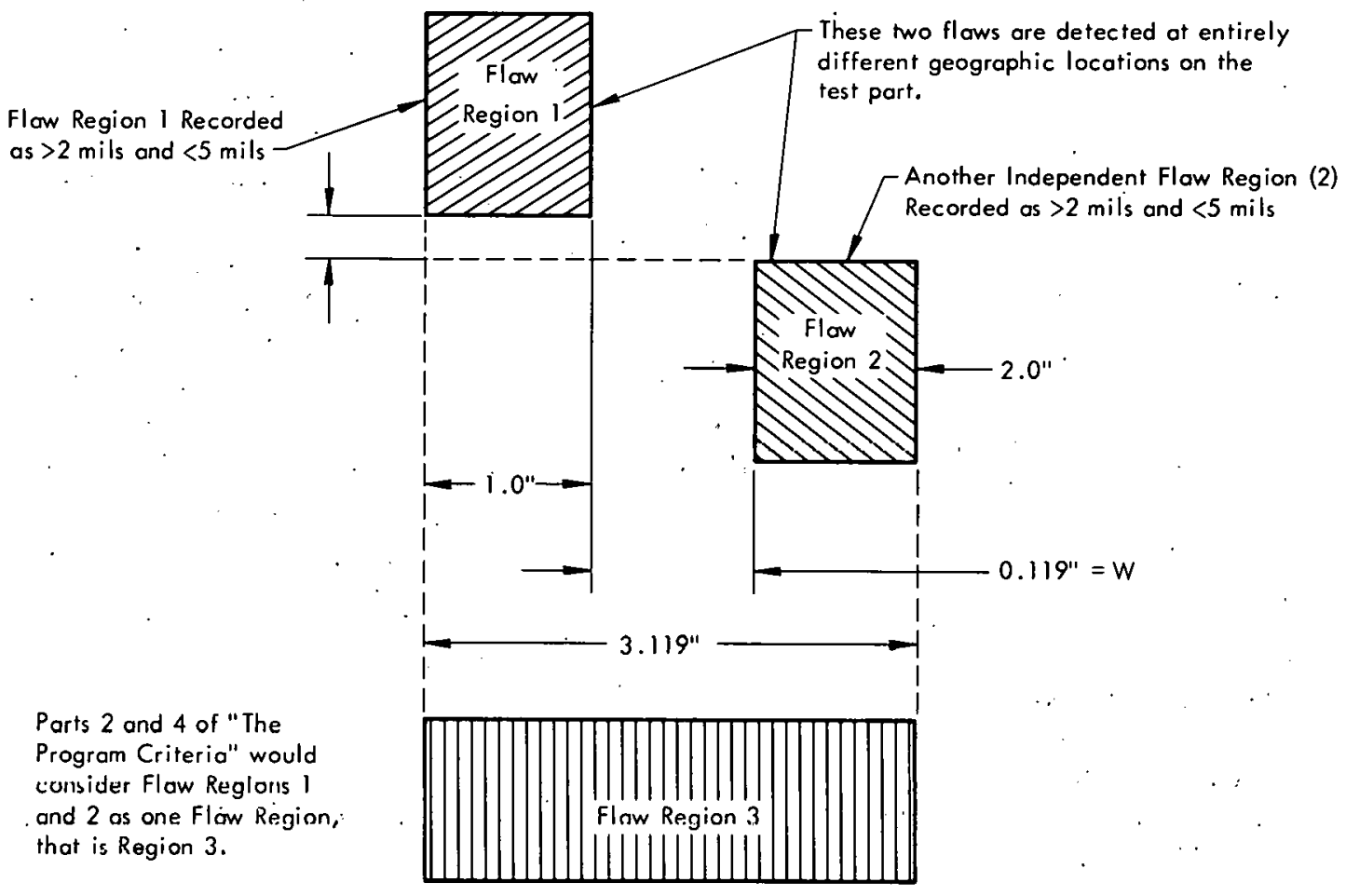

Figure 6. ILLUSTRATION OF OVERLAP CRITERIA. (Not Drawn to. Scale) ·

\section{GENERAL DESCRIPTION OF THE COMPUTER PROGRAM}

A pictorial description of the FOCAL ultrasonic data analysis computer program is given in Figure 7.

The digitized values of known flaw signals obtained from a standard are the initial input data to the computer. Next, the number of passes that the computer will analyze is also entered manually from the teletypewriter. (The number of passes needed will vary with the weld root width and may not always he the same.) 


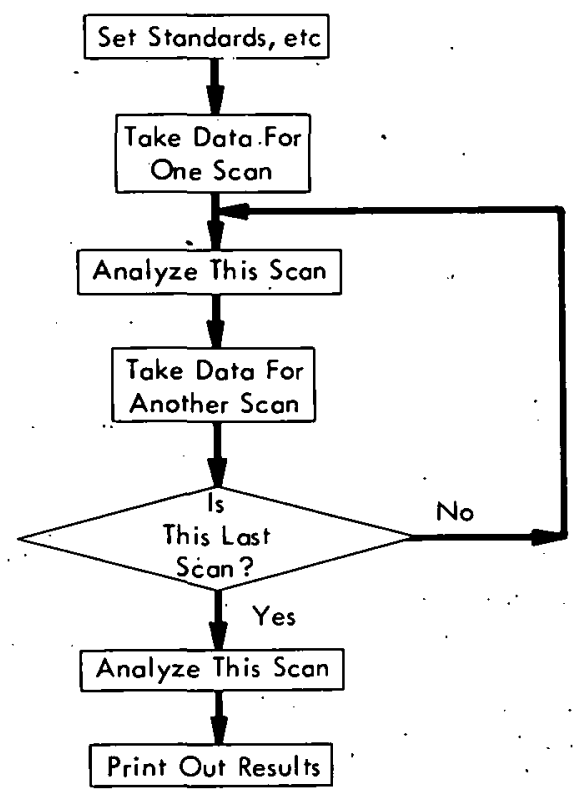

Figure 7. FLOW CHART FOR THE "CUDAS" "FOCAL" PROGRAM.
The FOCAL program is designed to provide a continual check to see if flaw amplitudes (in digital form) are greater than a standard digitized value for a 2-mil-deep slot. When a flaw indication exceeds this threshold, the program interrupt facility (using machine language) checks the encoder information as to the location of the beam on the part. An instant later, the FOCAL program resumes its job of categorizing the flaw indications with respect to standard determinations from 2, 5, and 10-mil-deep slots.

The FOCAL program then checks to see if the data collection for the present scan is completed. If the data collection is : not completed, the FOCAL program continues to monitor the digitized data (refer to Figure 7). After a scan has been completed, the data taken are analyzed, and the FOCAL program checks to see if this was the last required scan. If the last scan has been completed, all data are analyzed, and the computer prints out an accumulated result, as seen in Figure 8. If the last scan has not been completed, the operator then indexes the transducer to the next scan and signals the computer to proceed. The computer will then start taking digitized ultrasonic data when the encoder reaches the "start" position on the part. The program also increments the completed scan count by one.

The present ultrasonic data analysis program could be modified to start and continue automatically from scan to scan and print out the final results at the completion of the test. This improvement would reduce the amount of control manipulation by the operator and the amount of typing by both the operator and computer.

\section{SYSTEM TEST RESULTS}

Tests were conducted to determine the effectiveness of the computer ultrasonic data analysis system (CUDAS) compared to the manual analysis scan system (MASS). (Compare Figures 5. and 9.)

It was found that the metal test parts could not be moved as rapidly past the ultrasonic transducer with the computer data analysis system as with the noncomputerized manual ultrasonic inspection system. The computer test could perform at only about one third the speed of the normal manual test because a particular small flaw signal has to remain above a predetermined threshold voltage level for a period of time that is sufficiently long to allow the ADC-FOCAL program-FOCAL compiler-computer circuits to recognize the signal as the beginning of a flaw. If the digitized flaw signal which is the input to the computer is not of sufficient width (determined by the speed of the test part relative to the transducer), then the computer-program compiler may not have sufficient time to recognize the flaw signal before it has disappeared. Also, the FOCAL programming language is relatively slow. With a faster programming language-compiler and/or a faster digital computer, it would be possible to run the test parts at a much higher speed. 
The qualitative/quantitative ultrasonic test results for 21 different test parts were obtained with both the MASS and the CUDAS. The computer system produced results for flaw magnitude, flaw location, and flaw accumulation which closely agreed with the manual system results.

Some explanations for the differences between the results obtained by the two systems are:

1. Round-off error in the flaw width.

2. Error in the chart-event marking of the weld location which was done manually by the operator.

3. Error due to nonuniform strip-chart lengths. Efforts were made to hold this variation to 10 percent.

4. A linkage error existed between the pulley-driven encoder and the drive shaft of the C-scan recorder (Figure 5). This error is being corrected by mounting an encoder directly to the drive shaft of the scan system for the test part.

The flaw lengths in Figure 8 are shown in degrees instead of inches, because the shaft encoder gives a position readout in degrees.

The following two statements perhaps deserve considerable attention in arriving at a decision as to whether or not a computerized system is advantageous:
EG

$* \mathbf{G}$

ENTER SAT. VALUF: SA

ENTFR STA.VDARD VALUE DR START: I

ENTER STAVDARD VALUE OR START: 5

FNTER STAVDARD VALUE OR START:?

FNTFE STAVDARD VALUE DR START:G

ENTER NUMRER DF PASSES: 6

PASS COMPLETE

TYPE G WHEN READY FOR NEXT PASS:G

PASS COMPLETE

TYPE G WHEN READY FOR NEXT PASS:G

PASS COMPLETE

TYPE $G$ WHEN READY FOR VEXT PASS:G

PASS COMPLETE

TYPE G WHEN READY FOR VEXT PASS: G

PASS COMPLETE

TYPE G WHEN READY FOR NEXT PASS:G

PASS COMPLETE

TEN MILL FLAW TARLE

$\begin{array}{lll}=\quad \begin{array}{l}\text { LOCATION } \\ 343.99 A 9=\end{array} & \begin{array}{l}\text { LENGTH } \\ 2.699 G=\end{array} & \begin{array}{l}\% \text { SATUKATIDN } \\ 95.4791\end{array} \\ \text { TOTAL ACCUMULATION OF TEN MILL FLAWS } & 2.699 A\end{array}$

FIVE MILL FLAW TARLE

$\begin{array}{rr}\text { LOCATION } & \text { LENGTH } \\ 343.7 \text { GAG }= & 3.299 A\end{array}$

TOTAL ACCUMULATION OF FIVE MILL FLAWS= 3.2 MGด TWO MILL FLAW TARLE

\begin{tabular}{|c|c|c|c|}
\hline & OCATION & & LENGTH \\
\hline$=$ & $84.1909=$ & & 1.29ดด \\
\hline$=$ & 97. & & 2.6999 \\
\hline$=$ & $139.3009=$ & - & 2. 5ดดด \\
\hline$=$ & $160 \cdot 3990=$ & $\cdot$ & 1.5900 \\
\hline$=$ & $168 \cdot 3999=$ & & $2 \cdot 2090$ \\
\hline$=$ & $229 \cdot 19 a 9=$ & . & 1. 5ด0a \\
\hline$=$ & $2.51 \cdot 69 a 9=$ & & 1.9000 \\
\hline$=$ & $256.9909=$ & & 1.2000 \\
\hline$=$ & $312.6000=$ & & 1.5000 \\
\hline 口 & $334.1949=$ & & 1. ВАВВ \\
\hline & $343 \cdot 5909=$ & & 3.9990 \\
\hline
\end{tabular}

TOTAL ACCUMULATION OF TWD MILL FLAWS= $21.9009 *$.

Figure 8. COMPUTER ANALYSIS PRINTOUT. 


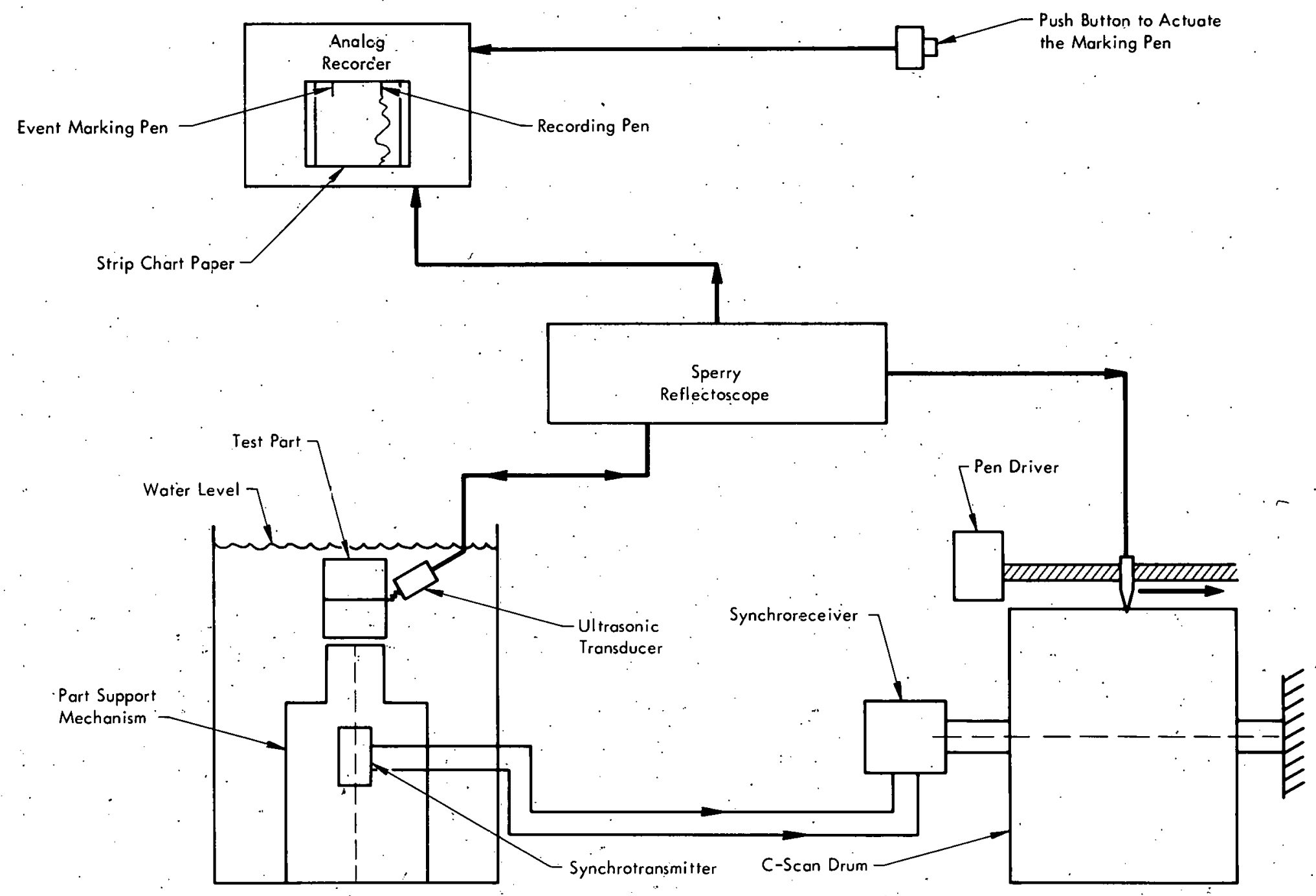

Figure 9. INFORMATION FLOW FOR THE MANUAL ANALYSIS SCAN SYSTEM (MASS): 
1. A computerized system may be attractive in areas which require extraordinary amounts of time to reduce and analyze the data from each test. An example of this is in the testing situation described in this report where six discrete criteria had to be evaluated to describe the quality of the weld.

2. A computerized system can be easily justified for applications where subcritical information is available and where its routine surveillance forewarns of defective and unsalable products. Industries producing costly items at rapid production rates should take a close look at the things this type of system could do for them. 


\section{ACKNOWLEDGEMENTS}

Among those who were instrumental in making CUDAS a success were: G. R. Boser and W. W. White of the Oak Ridge Y:12 Plant, and R. C. Maxon of the Rust Engineering Company.

Special recognition is given for the contribution of $R$ : $E$. Neal who wrote the computer programs for CUDAS: 